\title{
Consumer Culture and the Design of a Modern Self in Iran: The Cultivation of Mind and Body in Iranian Lifestyle Magazines
}

\author{
ARIANE SADJED \\ University of Vienna, Austria
}

\begin{abstract}
This paper examines two distinct forms of how a modern Iranian self is crafted in relation to and in negotiation with Western modernity. Consumption as a way of forming and expressing identities is a strongly contested practice in Iran, where identity politics have changed drastically after the Islamic Revolution of 1979. An examination of the visual and discursive material from two contemporary Iranian lifestyle magazines shows that practices such as managing and disciplining the self and the constant improvement of one's personality and body are an important part of the public discourse in Iran. They are reflected in the journals by endorsing different products, tastes, and choices of lifestyle. Analysing the magazines' strategies to address different income groups brings to light distinct ways in which practices of modern self-management are embedded in an Islamic framework. As will be demonstrated, the journal targeting high income-level groups frames the successful self almost exclusively in relation to the outward appearance while the more middle class-oriented magazine instead engages in discourses based on religious or moral values. Refuting perspectives focused on religious or cultural identity exclusively, the paper points to the socioeconomic background as an influential factor in the process of conceptualising images of a modern Iranian self.
\end{abstract}

\section{Keywords}

Iran, lifestyle magazines, selfhood, modernity, neoliberal ethics

\section{Introduction}

In October 2013, Israel's Prime Minister Benjamin Netanyahu stated in an interview that if "the Iranian people had their way, they' $\mathrm{d}$ be wearing blue jeans, they'd have Western music, they'd have free elections" (BBC 2013). This statement was followed by an uproar on social media, with many young Iranians posting pictures of themselves via Twitter wearing blue jeans and showing their iPads - the latter displaying a playlist with 'Western music' (Guardian 2013). The message was clear: Iranians are well-acquainted with what is considered modern, and they proved it by showing their affiliation to Western fashion, culture, and lifestyle. Most Iranians, who spoke out against the accusation of not being able to live a 'modern' life, however, did not question the identification of being modern with a Western lifestyle - which is remarkable since the independence from Western influences has been a hallmark of the Islamic Republic for the past thirty years. As Mr. Netanyahu went on to explain that the people of Iran and Israel had a "deep friendship into modern times" that had been destroyed by Iran's current government, 
the juxtaposition between a Western lifestyle, freedom, modernity, and consumerism on the one hand, and Islam on the other hand was all the more emphasised. A Western lifestyle is formulated as the epitome of freedom, ruling out any other choices that do not resort to this very particular form of consumerism.

This article takes up the construction of a Western lifestyle representing an antipode to Islamic culture as a means to analyse modern identity creation. The article will challenge this dichotomy by examining Islamic concepts regarding modernity and the self in two selected lifestyle magazines, which reveal a variety of ways in which 'the modern self' is conceptualised and implemented. As the article will show, lifestyle choices are less motivated by a particular urge to resist Islam or a religious government, but by class aspirations, social inequalities, and last but not least, the symbolic and universal power of Western consumer goods to represent very particularistic notions of individual freedom and modernity.

The article will first introduce the role of consumer culture in Iranian society from a historical perspective. The Iranian consumer society will then be contextualised in its relation to the global political and economic contacts with the West, that is Europe, and from the mid-twentieth century onwards, the United States. From this background two contemporary lifestyle magazines will be compared in regard to how they construct a modern Iranian identity and how they combine Islamic with consumer-oriented lifestyles in different ways.

\section{Methodology}

This article is part of a larger research project for which ethnographic fieldwork was conducted in Tehran. A quantitative survey was carried out focusing on consumption choices among the urban middle class with a weighed sample of 134 respondents as well as fourteen qualitative problemcentered interviews (Sadjed 2012). Participant observation in shopping centers in central Tehran, as well as in Northern and Western parts of the city was combined with a content analysis of lifestyle magazines. This article will focus on the analysis of lifestyle magazines. It will deal specifically with how modern identities are constructed and diffused by distinct media in Iran. It will not address the reception of these magazines by their audiences.

The Iranian media landscape is diverse and has a long-standing tradition. According to the Iranian research institute Namaye ${ }^{1}$, there are currently more than one hundred magazines published in Iran. However the data does not 
allow conclusions as to exactly which magazines are currently published. During fieldwork in Tehran, five different lifestyle magazines that were currently published were found at the newsstand (Sadjed 2012). For this article two were selected: Donyā-e Zanān (Women's World) and the glossy magazine Zendegi-e Ideal (Ideal Life). While the other three magazines contain articles about fashion, housekeeping, home decoration, celebrities, beauty, etc., Donyā-e Zanān and Zendegi-e Ideal also feature articles on how to become or to behave as a modern and confident Iranian (woman). They thereby present two distinct forms of modernity: as will be shown below, Donyā-e Zanān actively combines a progressive lifestyle with Islamic ethics. But although it purports Islamic values, it cannot be seen as the voice of the Iranian government. It rather opens up a space of Islamic modernity from 'below'. Zendegi-e Ideal on the other hand resorts to Western aesthetics and styles that only elites in Iran can afford. Obviously, this selection does not claim to be representative for the lifestyle magazines in Iran. Rather, due to their exemplary and contrasting character, they qualified for deconstructing false dichotomies in which a Western lifestyle is equated with modernity and freedom whereas Islam stands for backwardness.

While Zendegi-e Ideal is one of the most popular magazines, Donyā-e Zanān is less widely distributed but was selected due to its focus on women. ${ }^{2}$ Other than well-known and extensively analysed magazines such as Zanān or Zane Emrooz, Donyā-e Zanān does not take up sociopolitical focal points, but is explicitly concerned with questions of 'lifestyle'. For the evaluation period of 2008-2010 I had several issues of each magazine at hand. I selected articles, images, and advertisements that a) conveyed moral and/or physical instructions on how to represent a modern Iranian self and b) challenged the dichotomy between Islamic tradition and Western modernity. The result of my analysis rendered one issue of Donyāe Zanān and two issues of Zendegi-e Ideal as most suitable for this article because they contain contrasting images and text material in regard to the two points mentioned above.

Concluding from their prices as well as their design and layout, Donyā-e Zanān caters to a lower middle class and middle class audience, while Zendegi-e Ideal targets the upper middle class. Considering these two different target groups, it is the aim of this article to show how exercising modernity in Iran is not primarily a matter of religiosity but closely tied to class differences. The two magazines exemplify two very distinct strategies of representing a modern self that are qualified for a comparison in order to

2 For the role of women as markers of modernity and nationhood in Iran see Najmabadi (1991). 
show not only the broad range of ways to implement the 'modern' in Iran but also how these approaches are informed by socioeconomic differences.

\section{Consumer culture in Iran}

The role of consumer culture as a corollary of democratisation as well as hegemonic structures has been the focus of scholarly interest in a variety of disciplines (Abu-Lughod 1990; Douglas and Isherwood 1979; Fiske 2000; McKendrick 1985). Consumer products can be statements of taste and express the individuality and freedom of choice of their owners. They can also be markers of distinction, used in the negotiation and expression of social hierarchies. People use consumption to "communicate to others their relationships to complex sets of otherwise abstract social attributes (such as status), thus identifying themselves within social structures" (Leiss et al. 1986: 243). While the marketing industry has been working continuously on associating certain goods with feelings of freedom and adventure, modernity, and prosperity, the symbolic value of a commodity unfolds only by taking the respective social, political, and economic context into consideration.

Regarding Iran, this contextualisation is important for two reasons. First and foremost, in Iran, the association between Western brands and freedom, wealth, and modernity has a somewhat different trajectory than in most Western countries. The historical and political history of (Western) consumer culture in Iran is thus crucial for understanding the social significance of consumption practices in Iranian society today. Secondly, mainstream Western perspectives on the expansion of global consumerism in Iran tend to position related forms of consumption as a kind of resistance against 'Islamic' culture. Many contemporary accounts of Iran in Western media differentiate - more or less subtly - between 'modern' and 'traditional' Iranians, primarily by their outward appearance. On one side of the spectrum there are young, fashionable women, their headscarf loosely attached to well-trimmed hair. While no attention is paid to their own reasons for personal style, Iranian women who conform to this image are often described as being subversive to the Iranian regime because of their choice of Western fashion and consumer goods such as designer-bags or mobile phones. ${ }^{3}$ On the other side of the spectrum, their counterpart is the backward, fanatic Islamic woman, epitomised by a full-length black chädor and deprived of any individuality. This figure tends to be depicted as submissive to the mass, incorporated into

\footnotetext{
A few examples are: Independent (2009); an interview with the Iranian-American artist Shirin Neshat in the left-leaning German online news service heise under the title "It is Also Shocking How Beautiful They Are" describes the resilience and resistance of Iranian women against the Iranian government in connection with the Green Revolution (Telepolis 2009).
} 
the state or in chaotic and emotionally highly charged situations (Knoblauch 2009; Deutsche Welle 2013; Esfandiari 2013).

The central argument of this paper is that by idealising Western-style consumerism under the pretense of promoting freedom or resistance in Iran, actual forms of self-determination that resort to an Islamic framework, including critiques of global capitalism, are silenced. These processes are based on a very narrow and essentialist understanding of the role of religion in Iran, fetishising Islam as isolated from the economic, political and cultural contexts in which it evolves. They also entail normative assumptions about how social change in Iran should come about and which allegiances are desirable in this process. Rather than enhancing or strengthening democratic processes, this perspective represents a continuation of the historical desire of Western powers to spread a consumerist lifestyle on the Iranian society (Karimi 2005) and, as a consequence, to reinforce their influence in this region.

In Western Europe the so-called 'consumer revolution' (Siegrist 1997: 18) began in the mid-nineteenth century as a result of profound economic and political transformations. The extension of consumption practices to different social strata challenged traditional hierarchies that were derived from fixed social positions assigned at birth (McKendrick 1985: 78) and - albeit far from being an uncontested or peaceful process - in the long run contained a "democratisation of desire" (Leach 1993, Williams 1991). However, twentieth-century Iran displayed a very different social setting: the reform and liberalization policies of Mohammad Reza Shah Pahlavi (in office from 1941-1979) were mainly aimed at economic growth, excluding large segments of the society from the political sphere, and actively suppressing democratic movements (Ansari 2000). Consumer culture was established on a large scale during the Pahlavi era (1925-1979), especially from the 1950s onward. The introduction of new forms of consumption was heavily influenced by European, and later, American models. The Shah aimed at importing the lifestyle of the European upper middle and upper class by enforcing upon the Iranian society imitations of what he considered as modern. The project of crafting a modern nation promoted education and modern science through the construction of hospitals and schools (Shayegh 2002: 348). However, alleviating class differences and enhancing the status of lower classes was not on the agenda. It was mainly the upper classes that were able to afford the new lifestyle and economic opportunities while the growing number of the urban poor were increasingly exposed to the state's law and order policy without benefits. Western fashion and lifestyle provided the cultural, economic, and symbolic capital for the new middle class to distinguish itself from the existing social strata. The resistance that formed against these processes was mainly centered on what was perceived as a superficial 
emulation of the West under which a grave social disequilibrium was brewing. Rather than simply being a sign of a pro- or anti-Western attitude, consumption practices in Iran made and still make the social stratification of society quite visible.

For two decades exports from the US to Iran grew so strong that the Iranian market was flooded with American products in the 1970s (Karimi 2005). These products were advertised in Iran's popular press and women's magazines and the commercialisation of everyday life penetrated private spheres such as the household. The magazines were also filled with pictures of glamorous Hollywood beauties, whose aestheticised faces symbolised an ideal for many Iranian women. The discrepancy between the pictures in print media and TV advertisements on the one hand and the daily life of many Iranians on the other led to a broad range of forms by which Iranians imported the 'American Dream' into their lives.

The symbolic meaning of Western brands that was established during the Pahlavi monarchy was rejected after the revolution of 1979. Yet although the Islamic Revolution aimed at overthrowing and reframing the notion of modernity established by the previous regime, many of the symbolic associations mentioned above persist. Despite the fact that an open and overly excessive display of Western lifestyles is restricted in Iran, European and American brands and lifestyles are used to demonstrate wealth, good taste, and a cultivated self - in other words, a form of cultural and symbolic capital (Bourdieu 1985) that allows for an elite consciousness. At the same time, the post-revolutionary regime has encouraged the development of tastes and lifestyles that include norms expected of a devout Muslim. In this process, it is not countering modernity per se, but its association with Western symbols; The Islamic Republic strives to create a 'modernity' that encapsulates the signs of Islamic life (Adelkhah 1999). In this way, habits of consumption have become central markers of internal cultural difference. Furthermore, wealth is not confined to a secular upper class anymore, and it would also be too simplistic to assume that only the poor devote themselves to an 'Islamic' lifestyle.

As will be demonstrated, the expansion of globalised consumer culture in Iran since the 1990s is not a subversive current of particularly liberal incentives positioned opposite the Islamic government. Rather, it has merged with new sets of demands, norms, and hierarchies that have blended with Islamic values and Iranian identity politics in a variety of ways.

\section{Global consumer culture and the economy of Iran}


Behdad and Nomani's (2006) study about class structure in postrevolutionary Iran describes a constantly changing situation, with upward mobility for certain groups in some periods and downward mobility for others, including a dramatic reversal of fortunes. In the first years after the revolution Iran experienced a profound economic crisis, the downfall of capitalism and rise of the petty bourgeoisie. Due to the crisis in the oil market in the mid-1980s and the war with Iraq, Iran was forced to follow an economic liberalisation strategy. The government had to pull back from many of its populist and revolutionary slogans for the 'powerless', and started an ambivalent economic agenda, in which capitalist relations were eventually reactivated. Behdad and Nomani state, "the Islamic-revolutionary discourse has changed and if the high-rise luxury apartments in the skyline of Tehran reflect anything, the 'oppressed' (mostazafan) are 'out' and the 'arrogants' (mostakbaran) are back 'in', all thanks to the Bonyad[-e] Mostazafan, the largest real estate developer in the country" (Behdad and Nomani 2006: 197).

The liberalisation policy of president Hashemi Rafsanjani in the 1990s was followed by a political and economic liberalisation policy during the eight years of Mohammad Khatami's presidency. During this period, the middle and upper classes were able to accumulate wealth, but due to the uncertainties of the market, fluctuating oil prices, and corruption the distribution of wealth was very uneven. Against this background, strong aspirations to social mobility and frustration about lacking economic possibilities are crucially influencing the urban population in Iran. The threat of being outflanked by the upwardly mobile, or one's own increasing economic hardship has exacerbated social hierarchies. These highly instable contestations for cultural and social capital in the changing economy of Iran are mirrored by tastes, desires, and consumption choices. Zuzanna Olszewska thus contends: "when working-class girls mimic the more 'daring' fashions of the upper-class girls, for example, they may in fact be signaling their aspiration to upward mobility more than the upper class girls' avowed defiance of the state's imposed norms of modesty" (Olszewska 2013: 844).

When Mahmoud Ahmadinejad was elected president in 2005, he initially suspended many economic reforms of the previous years but gradually came to embrace them after imposing modifications that reflected his ideological views and political interests. Mr. Ahmadinejad's economic policies were aimed at enhancing the status of lower-income groups but initially benefitted the revolutionary armed forces, leading to the "militarization of the Iranian economic and banking systems" (Habibi 2013: 6), among them also the religious endowment Bonyad-e Mostazafan mentioned above. In an attempt to reduce inflation and improve the living standard of ordinary people as he had promised, president Ahmadinejad allocated a large proportion of oil 
revenues to imports and to consumers directly. These policies, along with a failed privatisation agenda have hurt producers and led to more involvement of the state and parastatal organisations in the economy (Alizadeh 2014: 9094).

The following analysis of two lifestyle magazines published during Mahmoud Ahmadinejad's presidency reflects the simultaneous trends of increasing consumerism, a precarious economy, and religious nationalism (Ansari 2012) which marked this period.

\section{Morality and self-realisation: Donyāe Zanān (Women's World)}

Donyā-e Zanān costs the equivalent of one USD and has a circulation of 50.000 copies per monthly edition. It was founded in 2005, is published monthly, and comprises approximately sixty pages. The magazine is financed by a private institute called Moasese Farhangi Donyāe Zanā̄ (Cultural Institute Women's World). In a telephone inquiry the business manager, Ms. Latifpour, said that the magazine receives no state funding. Most authors, as well as the chief editor, are women.

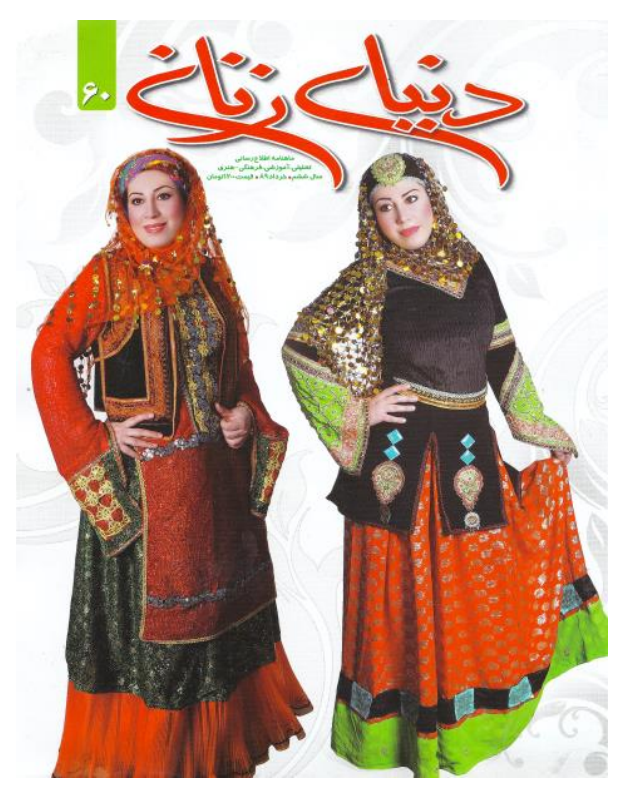

Image 1: Cover of Donyāe Zanān, 2010

The style of the typography on the cover of issue no. 60 (May/June 2010) combines a traditional form of calligraphic print with a modern design. Modern Persian computer fonts were introduced in Iran in the early 2000s 
and the use of this technology and knowledge of software can be considered as one of the yardsticks by which progress is measured and imagined in Iran. ${ }^{4}$ In Donyā-e Zanān, this style is used for religious content, the magazine thus positioning itself as modern-Islamic. The magazine opens with a letter from the editor that uses polite forms of address expressing traditional Islamic values of modesty and respect, e.g. signing the letter with "your little sister." In an introductory text about the importance of the month Shaban, in which the twelfth Imam was born, the editor repeatedly cites various Imams and the Qur'an (in total fifteen times on one page), stating the editorial and thus the whole magazine as adhering to an Islamic framework.

Consequently, the cover story is a report about "Iranian clothing," under the motto of mixing a traditional (sonnati) with a modern ${ }^{5}$ style. Accessories and colourful elements from traditional Iranian folklore costumes are combined with new patterns and colours, thereby being reframed as modern. In the article, a woman donning a black chädor, shows off little female and male puppets wearing colourful folk dresses, riding on camels, and carrying small clay pots. Although the modernity of this style might not be evident at first glance, the combination of traditional elements and dress patterns is indeed new. The attempt to invent and invigorate a national fashion resorts to what is considered 'indigenous'. New forms of ethnic chic became increasingly popular in Iran during the presidency of the reformist Mohammed Khatami (1997-2005) (Zahedi 2007). However this pastiche of styles presented on the cover and the respective article in the magazine differs from the sophisticated ethnic chic worn by urban Iranian elites (Noori 2013): it represents 'flawed' knowledge about how to mix the styles according to what is considered as high fashion. It rather represents folkloristic styles prevalent among the rural population. When I talked with one of my interview partners, a 23-year old dancer who has travelled internationally, about fashion and outward appearance among youth in Tehran, she said: "Those with teased hair... the more teased they are, the less they are with themselves I think. And the boys with the spiky hair, they are funny. We laugh at them."

My interview partner distinguished herself and her peers from those who are 'inauthentic' and even ridiculous in their endeavours to be stylish. According to her view, they are not themselves, trying to imitate something they are not. In the polarised perspectives about a modern Self, these failed attempts of fashionability are considered as an unintentional exposure of one's lack of cultural capital, or the inability of the lower classes to acquire 'good taste'. In

\footnotetext{
4 Several of my interview partners stated that in the process of modernisation Iranians should select which aspects to adopt from the West: Modern technology was among the most favorable aspects, while others should be rejected.

5 The European word 'modern' has been incorporated into Persian.
} 
this dichotomous logic, those prone to a Western lifestyle are considered as superficial and morally corrupt because they are imitating fashions that are not authentically Iranian.

However the art of mastering style has to be seen in connection with understandings of class and cultural capital in Iran. Before the revolution, symbolic and cultural capital derived from the knowledge about European styles and trends. Until now, this form of capital ranks above financial capital, since the latter was often required after the revolution by showing one's loyalty to the Islamic Republic, notably less-privileged rural and urban residents, veterans of the revolution and the war with Iraq, and the traditional middle classes who had not benefited from Pahlavi economic policies. The former elites who were socialised in a time, in which European styles were the marker for progress, wealth, and cultivation, and dominated the access to cultural as well as financial capital, were disempowered by the revolution. The new lifestyles enforced by the revolutionary state are despised as lower class and 'peasant' (dehäti) by those who were excluded or excluded themselves from the new agenda. Against this background, the lack of knowledge about 'good taste' is expressed to dissociate oneself from these lower social strata, and raises the status of the speaker in a social hierarchy that prioritises an older, bourgeois idea of taste (Deeb and Harb 2013).

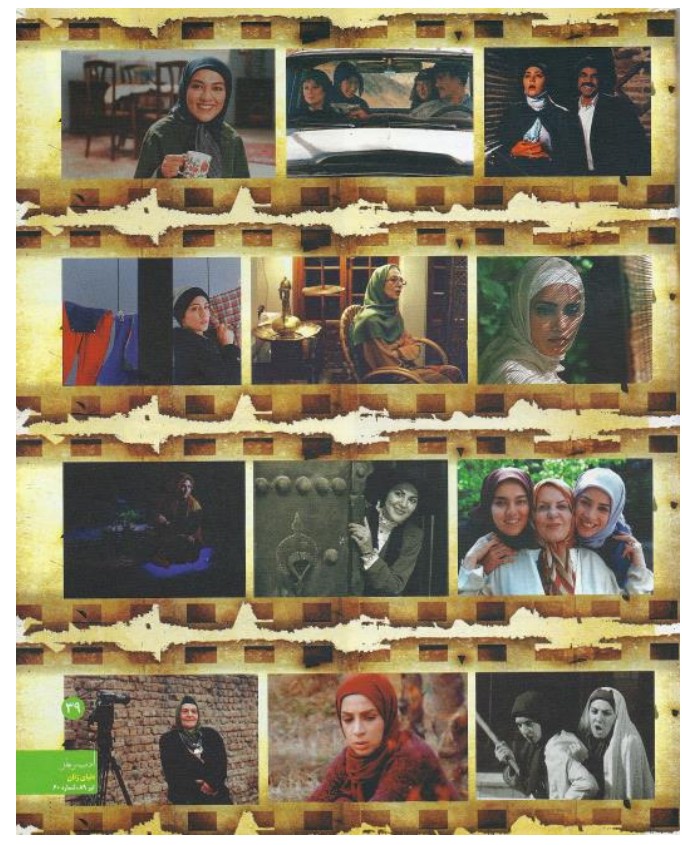

Image 2: Iranian actresses 
The lack of any gossip about celebrities and the distinct style of their depiction in Donyā-e Zanān also correspond with the concept and aesthetics of an Islamic magazine. For example, there is a double-page with photos of female Iranian actresses. In it, no bodily features are displayed, except for the face, with the hair of course properly covered. None of the pictures suggests any kind of sexiness or seduction based on the presentation of the body. Rather, there are scenes from movies depicted, with strong facial expressions and character actors. In this way, 'inner' values such as character traits are prioritised over the outward appearance, i.e. a seductive body and flawless face.

Another article captioned "Beauty Without Make-Up" contains the personal account of a woman who takes a course at a beauty institute. There, she notices that the teacher was very beautiful but did not wear any make-up. She approaches the teacher, asking why she was not wearing any make-up, and is told, "Simplicity is also beautiful." The two women then walk home together and have a nice chat over a cup of tea and some sweets. The author learns that the teacher has a husband but they do not have children, because they still need their time for "each other" and for cherishing their love. The teacher then gives the author of the article, who declares that she used to wear heavy make-up, some brochures and DVDs about "natural beauty." The article ends by stating that not only women have to be beautiful, but men also should take care of their looks. This story is interesting because it is obviously constructed to convey the moral message of using make-up moderately. The affectionate relationship that evolves between the two women romanticises the dispute about wearing make-up in Iran. While heavy make-up is proscribed by the conservative fraction of the government, it is also considered as vulgar and tasteless by cultural avant-garde groups of the upper middle class. By constructing the teacher as a woman who prioritises the romantic relationship with her husband over traditional values such as being a mother, the story integrates the rejection of wearing make-up as unIslamic with an utterly modern concept of womanhood that embraces individual satisfaction and emancipation from traditional female roles.

Donyāe Zanān also features an article about Jeanne D'Arc in the series "Women Who Have Moved the World." The article starts by explaining that women are often referred to as the "second sex," that they are purported to be delicate (latif), dependent, and irrational. But in reality, the author states, women can be very strong, have high self-esteem, and a strong spirit (ruhiyeh). On the last page of the magazine there are quotes from international figures such as Mother Theresa, Mahatma Gandhi, Judy Garland, Fyodor Dostoyevsky, Albert Schweizer, and Francis Bacon, as well as Iranian celebrities. The quotes express life wisdoms encouraging initiative, a strong 
mind, and drive for success. It seems to make little difference if these role models are Western (Christian) or Islamic, as long as they represent a form of self-confident spirituality that evolves around the topic of self-fulfillment.

The magazine furthermore contains many articles about health, in particular regarding balanced diets, as well as instructions for handicraft works for decorative objects in the household. Topics such as music, the arts, and handicrafts emphasise the importance of a "cultured self." It is encouraged that women be well versed in these areas, as opposed to wasting their leisure time in an unproductive and passive manner. The concept of free time as a time for learning, for acquiring new skills and cultural capital matches the strategy of Donyā-e Zanān to construct women and the domestic environment as a terrain for developing a strong 'Islamic personality' (Tripp 2007: 168).

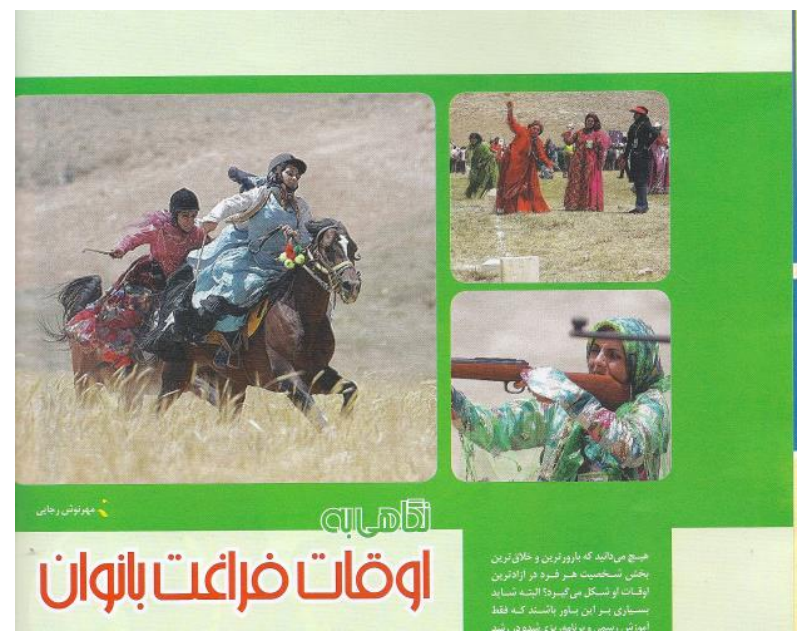

Image 3: Hobbies of Iranian women

Following Pierre Bourdieu (1985), practices of self-cultivation can be regarded as essential for the middle class in its strive for upward mobility. The concept of the cultivated woman as presented in Donyā-e Zanān thus engages a modern national, Iranian identity and demands of a global market culture, in which self-reliance and initiative have become crucial in order to withstand downward mobility.

In summary it can be stated that Donyā-e Zanān purports a notion of modern Islamic womanhood mainly targeted at lower middle class and middle class audiences whose desire for upward social mobility and modernisation is accommodated within an Islamic framework. The crafting of a controlled individual taught how to behave in a cultivated manner, while also exhibiting 
an active and engaged Islamic personality is a product of post-revolutionary politics in Iran. However, this process has to a certain degree developed its own dynamics that can no longer be fully controlled by the state. The modern, self-confident and active woman that the magazine propagates is neither a submissive victim of Islamic politics nor a subversive rebel against the regime. It is the space in between adopting and transcending modern Islamic identities that media such as Donyā-e Zanān explore.

While the practice of presenting one's inner life, emotions and tastes by means of the outward appearance is a central feature of modern consumer societies (Featherstone 2010), Donyāe-e Zanān prioritises character and inner values to what is considered a superficial and inauthentic emphasis on the outward appearance.

\section{Success and the able body Zendegi-edeal (Ideal Life)}

The proper and successful management of the self plays an important role also in the second magazine, Zendegi-e Ideal. However, its strategies and goals are quite different from the ones presented in Donyā-e Zanān. Zendegi-e Ideal is one of the leading lifestyle magazines in the urban centers of Iran. It was founded in 2007 and is a biweekly publication with a circulation of 75.000 copies per edition. It usually comprises of 160 pages and costs approximately two USD, targeting the upper middle and upper classes. An all-male board of directors oversees Zendegi-e Ideal. The concession for printing is owned by a private company, Haft Honar Sepid that, together with the private advertising company Peyk Bartar, finances the magazine.

Consequently, there is much more advertising than in Donyā-e Zanān. Most of the ads feature exclusive Western brands. The magazine has different categories, which are printed at the sidebar of every section in Persian and in English. Some of the categories are "Health," "Beauty," "Amazing World" (reports from all over the world ranging from humorous to bizarre), "Ideallife" (actors, TV shows, cars, household appliances, high-end food), "Faces" (Iranian celebrities), "Appearance" (clothing, perfume, and accessories), "Decoration" (furniture and decorative objects of the household), "Fitness," and "Kitchen" (recipes). 


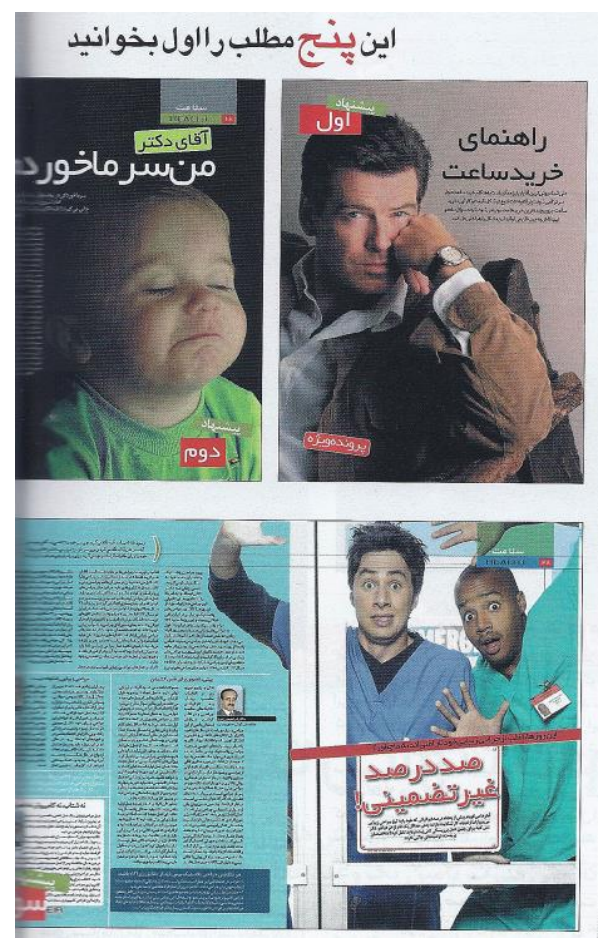

Image 4: Preview to Zendegi-e Ideal, 2009

The preview of Zendegi-e Ideal no. 30/2009 reveals a Hollywood star illustrating the theme of luxury watches, a blond child featured in an article about colds, and another health-related article embellished with pictures from the American TV-show Scrubs. The magazine - both formally and content-wise - heavily resorts to Western frames of reference.

When looking at the advertisements, household appliances are very prominent, but unlike Donyā-e Zanān, they feature much more expensive and exclusively European brands: ads for WMF or Versace tableware, Bosch washing machines display the same images and textual contents - sometimes not even fully translated - as the original, emphasising "European standards" or simply the name of the country of origin. The lack of adaptation of the textual and visual contents to the Iranian context can only partially be explained by the small advertising industry in Iran, which does not have many resources at hand. Instead it appears quite desirable to convey the European origins of these goods, as they represent quality and prestige.

Advertisements embracing the traditional, national heritage of Iran are also present: the company Iran Sofal Masoud (Ceramics) advertises antiqued 
furniture with slogans such as "Connecting to the Past" (Zendegi-e Ideal no. 30) or "We create a charming sense of an antique affection" (no. 29). The objects for sale, such as vases or statues, imitate antique patina. Iran Sofal Masoud also advertises 'modern' furniture that is based on European bourgeois and imperial aesthetics. While these latter styles of furniture would by no means be considered 'modern' in the context from which they are borrowed, this advertisement conveys how a modern, cultured taste is imagined by upper class Iranians, including the incorporation of an Orientalist gaze that reifies the Oriental and glorifies an imagined imperial culture of Europe and Iran.

However, there are also attempts to reconcile Islamic with upper class lifestyles: In no. 29/2008, there is a report under the headline Maryam-e pā' $\bar{z} e$ man ("My autumn-Maryam"). This is the title of a song from an Iranian popmusic band located in Los Angeles. The subheading reads: "This mall carries high quality as well as chic brands" (p. 99). A conservatively dressed woman is placed in a high-class shopping center. The building and the expensive goods displayed in the shop windows suggest that it is one of the upper class shopping malls in Northern Tehran. A woman completely covered with a black chädor, and a schoolgirl with maghna-e (head covering common among students and government employees) and in jeans are entering the building.

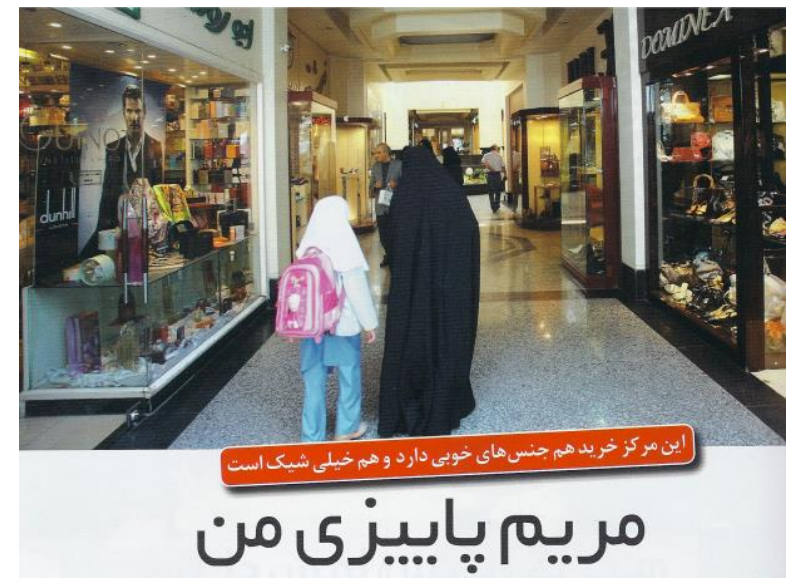

Image 5: A woman with a black chādor in a high-end shopping mall

In high-end shopping malls in Iran the number of women fully covered in chädors tends to be rather low. ${ }^{6}$ This particular image thus suggests that it was

\footnotetext{
The participant observations I conducted in Tehran shopping malls showed that women wearing a chädor were well represented in middle class shopping malls (regarding the price range of products and
} 
intended to establish a connection between an upper middle or upper class woman who appreciates fashionable and expensive goods while adhering to a conservative form of Islamic dress. However, this fusion of an Islamic lifestyle with high-class consumption is not very convincing: first, conservative and religious people would not necessarily find the hint to 'Tehrangeles' pop-music alluring. Second, the woman is only shown from behind, the reader cannot see her face or any other feature of individuality there is simply the black chädor. By depriving the woman of individuality and agency, the picture remains very ambivalent: what is her relationship to the schoolgirl? Could it be that the woman donning the chädor is her nanny? By leaving these options open the construction of a religiously conservative yet upper class woman fails.

In Turkey the rise of an Islamic bourgeoisie and the tastes and consumption choices connected with it ignited a "market war" over identities: Politics of identity between secularists and Islamists had become politics over symbols in the context of consumerism. For example, Yael Navaro-Yashin describes how middle class women experienced a loss of visible class identity when putting on the headscarf and were irritated when taken for a lower class person. The emergence of Islamic fashion in the 1990s finally allowed devout women to maintain their middle class identity (Navaro-Yashin 2002: 103). In Iran, the revolutionary discourse has also sought to rejudge available symbols of class and distinction, resulting in new middle- and upper classes that opt for conservative Islamic attire. Many of them strive to be pretty, modern, and fashionable as they practice their belief.

However, rather than the magazine's intention to expand the domain of middle- and upper middle class taste and lifestyles to include Islamic norms, the unconvincing way that the picture above is put together can be read as an attempt to avoid censorship. This can also be inferred from an article titled "Religious Lifestyle" in no. 39 from April 2009 that closes with a note from the editors stating:

Until now, we have reported about perfume, watches, fashion, hygiene, beauty, and food as a lifestyle. We never wrote about the meaning of life, although we always thought about it. We want to accomplish this now and put these themes forward. We appreciate the material and the common aspects of life but the spiritual meaning is also important to us (Zendegi-e Ideal 2009).

the neighborhoods in which the mall was located) and the bāzār. In high-end malls, visitors donning a chädor were much less frequent. 
Such statements, somewhat out of context and superimposed, must be seen in relation to the policies of the Ahmadinejad administration - in 2010, the magazine was threatened with a ban.

Advertisements for beauty institutes are very prominent in Zendegi-e Ideal as well, featuring "make-up artists from Hollywood" and experts with an "international certificate from France." Another ad reads: "We do everything European style and state of the art" (method-e rüz). Most beauty salons point out that they work with a cosmetic brand from the US (Peggy Sage), and emphasize that their employees are from Italy, France, or Canada. Western fashion and style is a sign of being up-to-date and 'high-class.' The pictures accompanying the ads however do not show any customers. The fact that women can only be pictured with a veil seems to contradict the commercial aesthetics of the magazine. Instead, one can see empty interiors of beauty salons, cosmetic surgeons, or flowers.

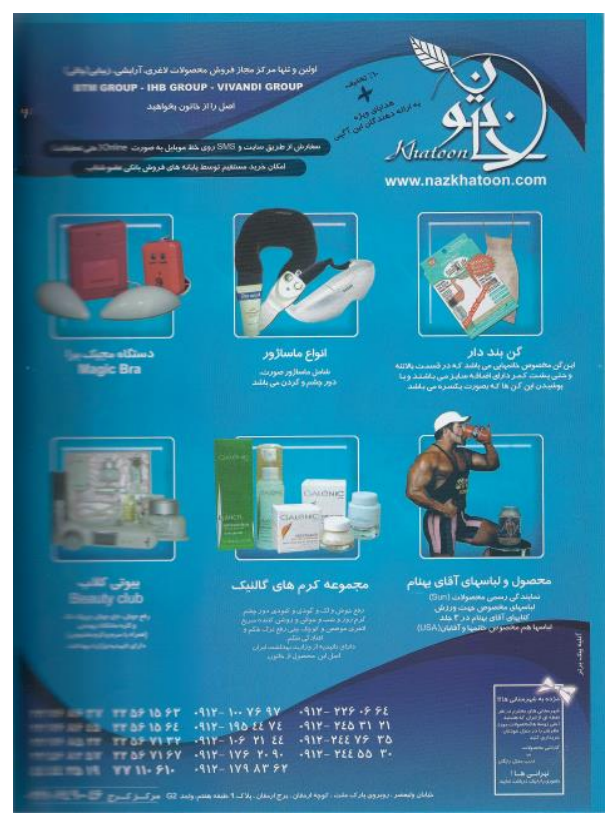

Image 6: Advertisements

On a single page, one can find advertisements for wellness centres, a Botoxlike gel, remedies against hair loss, products for teeth bleaching, liposuction, hair removal or hair implants, rhinoplasty, stomach stapling, artificial insemination, and several slimming institutes. In the section Ideal Clinic, 'professors' and medical doctors from different areas of expertise are prominently featured for Q\&As. The alteration of one's body through 
medication or surgery is a dominant theme. The body is a capital that constantly has to be modified, improved, and represented.

The fitness industry plays an important role in engaging particularly the middle classes in producing self-value, distinction, and prestige. In a world of increased competition, a toned, muscular body is equated with strength and vitality, and thus comes to symbolise the antithesis of fatigue, illness, or "moral flabbiness" (McGee 2005: 86). Against this backdrop diets, cosmetic surgeries, and fitness are rites of passage to a more disciplined and modern society through which individual shortcomings as well as perceived cultural deficits such as backwardness, disorder, and non-transparency can be overcome. These practices include not only pleasant practices of consumption and care, but also painful operations and labourious training. Since the number of plastic surgeries - especially rhinoplasty - is very high in Iran, the connection between self-modification and success suggests that alterations of the body have become a tool to seek and display social success.

Both magazines thus entail the fusion of Islamic or spiritual themes with Western self-management practices. This approach has become part of the social repertoire in Iran, regardless of one's religious or socio-economic background. The goals for which it is put to use however, do differ: in Donyā$e$ Zanan the cultivation of the mind is prioritised in order to build strong Islamic values, while in Zendegi-e Ideal these tools are mainly directed at the body in order to achieve material wealth and individual success. Other than Donyā-e Zanān, Zendegi-e Ideal includes strong esoteric elements, mainly infused by Western New-Age literature such as The Secret. ${ }^{7}$

\section{Conclusion}

Donyā-e Zanān, founded at the beginning of the Ahmadinejad-era, mirrors the respective cultural politics of creating a modern, Islamic-Iranian woman. The rigid policies under Ahmadinejad's presidency created a space for a magazine that is financed independently from the state, run by and for women. In Donyā-e Zanān, the modern woman appears in many different roles - as a housewife, athlete, artist, or taxi driver. The headscarf is worn, if not with pride, at least casually and not as a constraint. The independent Iranian woman leads a household with modern technology, and whether employed or not, she is cultivated and educated. In certain respects, Donya-e Zanān thus represents self-determination and agency of women in the Iranian

\footnotetext{
7 The internationally famous book The Secret by Rhonda Byrne has been on the best-seller lists in Iran for months with the Farsi translation in its tenth printing. The state-owned television station Channel Four repeatedly broadcast the book's companion video. The Secret builds on the concept that everything is accomplishable with the 'right' mindset, offering suggestions on how to direct one's thoughts in order to achieve success and happiness, including material wealth.
} 
public sphere. While it challenges some of the state's attempts to impose a normative modesty and control women's bodies, the magazine is still in line with creating an 'authentic' Iranian self. Most of the topics emphasise an inner state of self-confidence, authenticity, and fulfillment.

Zendegi-e Ideal provides a blank space here: the modern woman as imagined in the magazine cannot be depicted because the image clashes with the prescriptions of the Iranian authorities. Since a woman adhering to the prescribed forms of Islamic dress cannot be displayed as beautiful and successful, there is no graphic representation of women at all. Zendegi-e Ideal is more focused on aesthetics and outward appearance, struggling to accommodate an exclusive and glamorous lifestyle within an institutionalised religious context.

The two magazines target different income groups, and differ accordingly regarding their strategies and forms of how a desirable self is portrayed. The focus on the socio-economic context of the magazines shows that religion is neither the dominant nor the only factor in shaping concepts of the modern self in Iran.

Donyāe Zanān targets elements of the lower middle and middle class who are less intrigued by the promises of Western consumer culture. Instead, the idea of a national Iranian lifestyle serves as an umbrella for including elements from other cultures and religious traditions. For many pious Iranians, a modern identity does not mean to abstain from consumption but is rather defined by what, where and how one consumes to remain in harmony with religious principles.

By comparison, Zendegi-e Ideal disregards the concept of a national stronghold against the cultural and economic dominance of the West that the authorities in Iran have been eager to construct. The concept of modernity exclusively follows models of Western lifestyles. However, despite the conflicts its reverence to Western culture causes with the government it cannot be regarded as a subversive element in the social order of Iran. Following Fiske (2000), the styles and tastes propagated in the magazine are not a form of "popular pleasure" that emanate from socially marginalised groups. It rather advocates an upper class lifestyle that is only affordable for a small elite. In post-revolutionary Iran, Western styles can still be used as markers of status and cultural superiority and be displayed to express social hierarchies.

Against this backdrop, it is quite problematic that mainstream Western media tends to interpret the spread of consumerism in Iran as an act of guerilla-like resistance against Islamic authority. This perspective obscures the politicaleconomic imperatives that shape tastes and differences in the increasingly 
globalised Iranian society. To deduce liberal and thus anti-Islamic sentiments from lifestyles oriented on Western models is an oversimplification of the role of religion in Iran. Rather than conceptualising Islam as a monolithic and rigid set of norms opposed to consumer desires, this paper shows how Islamic values, imagery, and concepts are articulated with class aspirations, consumer desires and Western-imported ideas of individuality and selfrealisation - depending on the class position of the lifestyle magazines' audiences.

The construction of Western consumer culture in Iran as a form of liberation points to a continuation of a past in which Iran was politically, culturally, and economically under the tutelage of Western powers. Ultimately, this points to the symbolic and factual power of the West to define what social change should look like and which orientations are considered desirable in this process. Rather than supporting a plurality of attitudes and choices, this perspective bears the danger of a commercial aestheticisation of 'freedom' in Iran.

\section{References}

Abu-Lughod, Lila (1990) The Romance of Resistance: Tracing Transformations of Power Through Bedouin Women. American Ethnologist, 17(1), 41-55.

Adelkhah, Fariba (1999) Being Modern in Iran. London: Hurst.

Alizadeh, Parvin (2014) The political economy of petro populism and reform, 1997-2004. In Parvin Alizadeh and Hassan Hakimian (eds.) Iran and the Global Economy. Petro Populism, Islam and economic sanctions. London and New York: Routledge, 76-101.

Ansari, Ali M. (2012) The Politics of Nationalism in Modern Iran. Cambridge: Cambridge University Press.

Ansari, Ali M. (2000) Iran, Islam, and Democracy: The Politics of Managing Change. London: Royal Institute of International Affairs, Middle East Programme.

BBC (2013) Iranians mock Netanyahu over jeans comment. BBC News [Online, 7 October 2013]. Available at: http://www.bbc.co.uk/news/worldmiddle-east-24435408 [accessed: 29.01.2016]. 
Behdad, Sohrab and Farhad Nomani (2006) Class and Labor in Iran: Did the Revolution Matter? New York: Syracuse Univ. Press.

Bourdieu, Pierre (1985) Distinction: A Social Critique of the Judgment of Taste. Cambridge: Harvard University Press.

Deeb, Lara and Mona Harb (2013) Leisurely Islam: Negotiating Geography and Morality in Shi'ite South Beirut. Princeton: Princeton Univ. Press.

Deutsche Welle (2013) Iranian women are second-class citizens. Deutsche Welle [Online, 25 February, 2013]. Available at: http://www.dw.com/en/iranian-women-are-second-class-citizens/a16817367 [accessed: 29.02.2016].

Douglas, Mary and Baron Isherwood (2006) The World of Goods: Towards an Anthropology of Consumption. London: Routledge.

Esfandiari, Golnaz (2013) Khomeinis Granddaughter Gives Iran Some Tough Love. The Atlantic [Online, 15 January 2013]. Available at: www.theatlantic.com/international/archive/2013/01/khomeinisgranddaughter-gives-iran-some-tough-love/267196/ [accessed: 29.02.2016].

Featherstone, Mike (2010) Body, Image and Affect in Consumer Culture. Body and Society, 16(1), 193-221.

Fiske, John (2000) Lesarten des Populären. Wien: Turia und Kant.

Guardian (2013) Iranians hit back at Israeli PM by tweeting pictures of their jeans. The Guardian Newspaper [Online, 7 October 2013]. Available at: http://www.theguardian.com/world/iran-blog/2013/oct/07/iraniansisraeli-pm-tweeting-jeansisraeli-pm-tweeting-jeans [accessed 29.01.2016].

Habibi, Nader (2013) The Economic Legacy of Mahmoud Ahmadinejad. Middle East Brief no. 47, Crown Center for Middle East Studies, Brandeis University. Available at: www.brandeis.edu/crown/publications/meb/meb74.html [accessed 6 July, 2014].

Independent (2009) Lipstick revolution: Iran's women are taking on the mullahs. The Independent Newspaper [Online, 26 February, 2009]. Available at: www.independent.co.uk/news/world/middle-east/lipstick-revolutionirans-women-are-taking-on-the-mullahs1632257.html?action=gallery\&ino $=6$ [accessed 18.02.2016]. 
Karimi, Pamela (2005) Policymaking and Housekeeping: President Truman's Point IV Program and the Making of the Modern Iranian House. Thresholds, 30, 28-37.

Knoblauch, Elisabeth von (2009) Gefangen in Tradition (Captured in Tradition). Die ZEIT [Online, 15 September 2009]. Available at: www.zeit.de/kultur/literatur/2009-09/teheran-revolutionsstrasse [accessed: 29.02.2016].

Leach, William (1993) Land of Desire: Merchants, Power, and the Rise of a New American Culture. New York: Pantheon.

Leiss, William, Stephen Kline, Sut Jhally and Jacqueline Botterill (2005) Social Communication in Advertising: Consumption in the Mediated Marketplace. London: Routledge.

McGee, Micky (2005) Self-Help, Inc. Makeover Culture in American Life. Oxford: Oxford University Press.

McKendrick, Neill (1985) The Birth of a Consumer Society. The Commercialization of Eighteen-Century England. Bloomington: Indiana University Press.

Najmabadi, Afsaneh (1991) The Hazards of modernity and morality: women, state, and ideology in contemporary Iran. In D. Kandiyoti (ed.), Women, Islam, and the State. London: Macmillan, 48-76.

Noori, Maral (2013) Youth in Iran Part 3: The Politics of Fashion. The Iran Primer [Online,19 August 2013]. Available at: http://iranprimer.usip.org/blog/2013/aug/19/youth-iran-part-3-politicsfashion [accessed 18.02.2016].

Olszewska, Zuzanna (2013) Classy Kids and Down-at-Heel Intellectuals: Status Aspiration and Blind Spots in the Contemporary Ethnography of Iran. Iranian Studies, 46(6), 841-862.

Sadjed, Ariane (2012) Shopping for Freedom in der Islamischen Republik. Widerstand und Konformismus im Konsumverhalten der iranischen Mittelschicht. Bielefeld: transcript.

Shayegh, Cyrus (2002) Sport, Health and the Iranian Middle Class in the 1920s and 1930s. Iranian Studies, 35(4), 341-369.

Siegrist, Hannes (ed.) (1997) Europäische Konsumgeschichte. Zur Gesellschaftsund Kulturgeschichte des Konsums. Frankfurt a.M.: Campus. 
Smith Maguire, Jennifer (2008) Leisure and the Obligation of Self-Work: An Examination of the Fitness Field. Leisure Studies, 27(1), 59-75.

Tripp, Charles (2007) Islam and the Moral Economy. The Challenge of Capitalism. Cambridge: Cambridge University Press.

Williams, Rosalind (1991) Dream Worlds. Mass Consumption in Late NineteenthCentury France. Berkeley: University of California Press.

Navaro-Yashin, Yael (2002) Faces of the State. Secularism and Public Life in Turkey. Princeton: Princeton University Press.

Telepolis (2009) Es ist auch schockierend, wie schoen sie sind. Telepolis [Online 09 September, 2009]. Available at: www.heise.de/tp/blogs/6/145035 [accessed 18.02.2016].

Zahedi, Ashraf (2007) Contested Meaning of the Veil and Political Ideologies of Iranian Regimes. Journal of Middle East Women's Studies, 3(3), 75-98.

Zendegi-e Ideal (2009) Religious Lifestyle, Zendegi-e Ideal, 39, April 2009.

Zukin, Sharon and Jennifer Smith Maguire (2004) Consumers and Consumption. Annual Review of Sociology, 30, 173-197. 